\title{
TUNGGANG AIR PASANG SURUT DAN MUKA LAUT RATA-RATA DI PERAIRAN SEKITAR KOTA BITUNG, SULAWESI UTARA
}

\author{
(Tidal range and mean sea level in the waters around Bitung city, North Sulawesi)
}

Royke M. Rampengan ${ }^{1}$

${ }^{1}$ Fakultas Perikanan dan Ilmu Kelautan, Universitas Sam Ratulangi, Manado, Sulawesi Utara.

\begin{abstract}
Tunggang air pasang surut dan muka laut rata-rata merupakan variabel penting pada oseanografi. Penelitian ini dilakukan dengan tujuan untuk menggambarkan tunggang pasang surut dan muka laut ratafrata di perairan sekitar kota Bitung. Kisaran pasang surut dihitung dari perbedaan ketinggian tingkat pasang tinggi hingga surut terendah. Berarti permukaan laut diperoleh dengan menerapkan rumus Doodson filter dan metode admiralti. Hasil menunjukkan bahwa rata-rata kisaran pasang surut di air perbani adalah $63,4 \mathrm{~cm}$ dan $155,2 \mathrm{~cm}$ pada pasang purnama. Permukaan laut rata-rata tahunan adalah $154,5 \mathrm{~cm}$.

Kata kunci: Bitung, pasang surut, muka laut rata-rata.

Tidal range and mean sea level are important oceanographic variables, This research was carried out with the aim of describing tidal range and mean sea level in the waters around Bitung city. Tidal range was calculated from the differences in height of successive high and low tide levels. Mean sea level was obtained by applying filter Doodson formula and admiralty method. The results show that the average tidal range at neap tide was $63,4 \mathrm{~cm}$ and $155,2 \mathrm{~cm}$ at spring tide. The annual mean sed level dvas $154,5 \mathrm{~cm}$.
\end{abstract}

Keywords: Bitung, tidal range, mean sea level.

\section{PENDAHULUAN}

Daerah pantai Kota Bitung merupakan ruang yang sangat intensif dimanfaatkan. Secara aktual, dapat dijumpai berbagai fasilitas seperti pemukiman, bangunan pelindung pantai, pabrik pengalengan ikan dan tentunya pelabuhan taut, baik yang berskala lokal maupun antar puląo, dibangun pada kawasan daratan pesisirnya. Ruang perairan pantainya tentulah menjadi kawasan yang sangat sibuk oleh berbagai transportási angkutan air.

Pada bentuk pemanfaatan intensif seperti itu secara logis dibutuhkan pemahaman yang memadai tentang kondisi perăiran pantai. Salah satu kondisi yang sanga (perlu dipahami adalah menyangkut berbagai yáriabel pasang surut perairan. Variabel pasang surut yang penting untuk dipahami dalam hubungannya dengan pemanfaatan daerah pantai adalah tunggang air pasang surut dan muka taut rata-rata.

Penelitian terbaru menunjukkan bahwa kenaikan permukaan laut di masa depan dapat memiliki dampak yang signifikan terhadap pasang surut pada paparan Eropa (Pelling et al. 2013). Keadaan ini bahkan akan memberikan dampak lebih global pada semua daerah paparan di dunia. Tunggang air pasang surut (tidal range) sesungguhnya merupakan tinggi gelombang pasang surut (Pinet, 1992). Pipkin et al. (1977) dan Pugh (1987) memberikan definisi tunggang air pasang surut sebagai perbedaan ketinggian antara elevasi pasang dan surut berurutan.

Berkaitan dengan definisi di atas, secara 'logis dapat dipahami bahwa dalam pemanfaatan ruang di pantai untuk berbagai kebutuhan, harus dilakukan dengan memahami karakteristik tunggang air pasang surut. Secara geomorfologis, karakteristik tunggang air pasang surut menjadi dasar dalam analisis bentuk lahan di pantai (Pethick, 1997).

Pada bidang geodesi, ketinggian titik-titik di atas permukaan bumi umumnya dinyatakan terhadap permukaan air laut tertentu. Guna penentuan kedudukan permukaan air laut sebagai referensi tinggi, dilakukan pengamatan kedudukan permukaan air laut dalam selang waktu tertentu, misalnya harian, bulanan atau tahunan (Djaja, 1989a). Ratarata hasil pengamatan tersebut umumnya yang digunakan sebagai referensi tinggi.

Salah satu variabel pasang surut yang sering dijadikan sebagai referensi tinggi, adalah muka laut rata-rata (MLR/mean sea level) dan sering dinotasikan dengan So. MLR merupakan permukaan air laut yang dianggap tidak dipengaruhi oleh keadaan pasang surut. Walaupun besarnya nilai muka laut rata-rata dapat berubah, tetapi perubahan yang ada sangat kecil bila dibandingkan dengan perubahan muka laut aktual. Menurut Pugh (1987), perubahan dalam skala waktu yang panjang pada 
muka laut rata-rata umumnya berkisar pada $10-20$ $\mathrm{cm}$ per abad. Itulah sebabnya muka laut rata-rata dapat digunakan sebagai referensi ketinggian titiktitik di atas permukaan bumi. Demikian sebaliknya, muka laut rata-rata juga dibutuhkan sebagai referensi dalam penentuan kedalaman laut dan penggambaran peta batimetri. Walaupun menurut Tomczak dan Godfrey (2005), kondisi kenaikan permukaan air laut agak kompleks dideskripsikan dengan adanya faktor tektonik aktif pada kawasankawasan tertentu di daerah pantai.

Berdasarkan uraian sebelumnya, maka penelitian ini dilaksanakan dengan tujuan mendeskripsikan tunggang air pasang surut dan muka laut rata-rata di perairan sekitar Kota Bitung. Hasil perhitungan tunggang air pasang surut dan muka laut rata-rata selanjutnya dianalisis menurut deret waktu perolehan data pasang surut.

\section{METODE PENELITIAN}

Tunggang air pasang surut dan muka laut rata-rata dideskripsikan berdasarkan data pengukuran pasang surut yang dilakukan oleh BMG bekerjasama dengan Bakosurtanal. Peralatan pengukur dipasang pada lokasi dekat dengan pelabuhan Bitung pada posisi geografis $1^{\circ} 26^{\prime} 22,8^{\prime \prime} \mathrm{U}$ dan $125^{\circ} 10^{\prime} 34,6^{\prime}$ 'T. Data yang digunakan adalah serp pengukuran dari September 2008 sampai dengan Agustus 2009.

Tunggang air pasang surut dideskripsiden harian, dengan memperhatikan puncak pasang dan surut terendah setiap hari. Untuk membantu penentuan puncak pasang dan surut, data pengukuran pasang surut harian diplotkan ke datầ grafik pasang surut. Selisih elevasi antara puncal pasang dan surut terendah, dicatat sebagai tunggang air pasang surut pada hari yang bersangkutan. Data tunggang air pasang surut, selanjutyya dianalisis menurut periode umur bulan.

Data hasil pengukuran pasang surut harian, selanjutnya diotah untuk mendapatkan muka laut rata-rata harian dan muka laut rata-rata bulanan. Muka laut rata-rata harian diperoleh dengan menerapkan perhitungan muka laut rata-rata 39 jam, yaitudengan menggunakan filter Doodson. Menurut Suyarso (1989a) penggunaan filter Doodson mengikuti aturan sebagai berikut:

dimana:

$$
\mathrm{XT}=\frac{1}{30} \sum_{\mathrm{d}=-19}^{\mathrm{d}=19} \mathrm{~F}(\mathrm{~d}) \mathrm{H}(\mathrm{T}+\mathrm{d}), \quad \mathrm{d} \neq 0
$$

$\mathrm{F}(\mathrm{d})=(2,1,1,2,0,1,1,0,2,0,1,1,0,1,0,0,1,0,1)$

$\mathrm{H}(\mathrm{T})=$ elevasi muka laut terukur

$\mathrm{T}=$ jam tengah pengamatan (jam 12.00)

Muka laut rata-rata bulanan diperoleh melalui perhitungan dengan memanfaatkan metode
Admiralti, sesuai dengan yang diuraikan oleh Soeroso (1989b) dan Djaja (1989b).

\section{HASIL DAN PEMBAHASAN}

Data hasil pengukuran elevasi muka laut pada lokasi penelitian selang waktu September 2008 sampai dengan Agustus 2009 bervariasi dari pengukuran terendah sebesar $74,1 \mathrm{~cm}$ sampai elevasi muka laut terukur tertinggi $260,3 \mathrm{~cm}$. Berdasarkan data hasil pengukuran, diperoleh kedûdukan permukaan air pasang rata-rata saat pasang purnama selama setahun adalah sebesar $240.4 \mathrm{~cm}$, sedangkan kedudukan rata-rata permukasmair surut saat pasang purnama selama setahun adalah 85,2 $\mathrm{cm}$. Kedudukan rata-rata permukaan a air pasang saat perbani adalah $186,1 \mathrm{~cm}$ dan keđudukan rata-rata air surut saat perbani adalân $22,7 \mathrm{~cm}$. Untuk jelasnya, kedudukan beberapa level muka laut tersebut ditampilkan padaGambar 1 berikut.

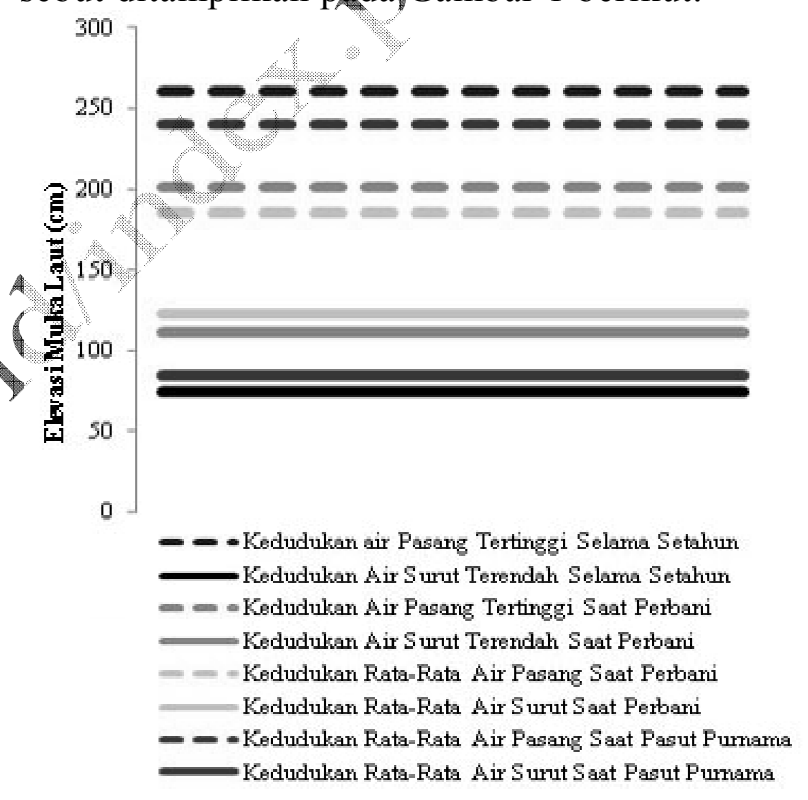

Gambar 1. Kedudukan rata-rata level muka laut saat pasut perbani dan purnama.

Figure 1. Position of the average level of the sea surface at neap and full moon tide.

Tunggang air rata-rata pasang surut saat perbani adalah $63,4 \mathrm{~cm}$ yang berfluktuasi dari $47,2-76,3 \mathrm{~cm}$. Pasang surut perbani terjadi dua kali dalam satu siklus umur bulan, biasa disebut perbani awal dan perbani akhir. Tunggang air terkecil saat periode umur bulan perbani terjadi pada tanggal 20 Maret 2009, sedangkan tunggang air terbesar saat periode umur bulan perbani terjadi pada tanggal 31 Mei 2009.

Pasang surut purnama terjadi saat memasuki bulan baru dan saat bulan penuh atau purnama. Besarnya tunggang air saat pasang surut purnama bervariasi mulai dari $137-182,5 \mathrm{~cm}$. Rata- 
rata besarnya tunggang air saat berlangsungnya pasang surut purnama ini adalah sebesar $155,2 \mathrm{~cm}$. Tunggang air terkecil terjadi pada 7 Juni 2009, dan terbesar terjadi pada 13 Desember 2008.

Menurut Pipkin et al. (1977), fluktuasi pada tunggang air pasang surut adalah merupakan respon dari orbit alami bulan yang berbentuk elips dan orbit bumi terhadap matahari yang juga berbentuk elips. Akibatnya terdapat suatu keadaan di mana bulan berada pada posisi terjauh dari bumi yang dikenal dengan istilah apogee dan sebaliknya dekat dengan bumi yang dikenal dengan istilah perigee. Keadaan yang sama terjadi pada jarak bumi dengan matahari yang dikenal dengan istilah aphelion dan perihelion (Stewart, 2008; Talley et al., 2011). Keadaan ini mengakibatkan adanya perbedaan gaya tarik dari kedua benda angkasa tersebut dalam pembangkitan pasang surut di perairan.

Pinet (1992) dan menyatakan, bumi berada pada posisi terjauh dari matahari selama berlangsungnya musim panas di belahan bumi Utara dan sebaliknya berada pada posisi paling dekat dengan matahari selama bulan-bulan musim dingin di belahan bumi Utara. Pada saat yang sama juga terjadi pada bulan, menurut posisi apogee dan perigee. Keadaan ini dapat terlihat jelas dampaknya pada tunggang air pasang surut saat pasang purnama. Tunggang air terbesar terjadi saat tanggal 13 Desember yang bersesuaian dengan berlangsungnya musim dingin di belahan bumi Utara se baliknya tunggang air terkecil terjadi pada 7 Juni bersesuaian dengan berlangsungnya musim panas di belahan bumi Utara.

Berdasarkan nilai tunggang air yang diperoleh, maka pasang surut pada kawasan penelitian tergolong pada microtidal. Sepertí yang disampaikan oleh Pinet (1992) dan Bird (2008), kawasan pantai yang digolongkan pada kategori microtidal adalah kawasan pantâyang memiliki tunggang air pasang surut maksimum kurang dari $2 \mathrm{~m}$. Dari sudut pandang geomorfologi pantai, menurut Pethick (1997), kawasan pantai dengan klasifikasi tunggang airpasang surut seperti itu, kerja gelombang angin sangat besar pengaruhnya terhadap proses maep n berbagai bentuk lahan yang ada di pantai.

Pada pengolahan data muka laut rata-rata, baik yang menggunakan filter Doodson untuk muka laut rata-rata harian, maupun dengan metode admiralti untuk muka laut rata-rata bulanan, hasil rata-rata tahunannya memperoleh hasil yang hampir sama. Hasil dari merata-ratakan nilai muka laut rata-rata harian memperoleh muka laut rata-rata tahunan sebesar 154,8 cm, sedangkan hasil merataratakan dari nilai muka laut rata-rata bulanan di- peroleh nilai sebesar $154,5 \mathrm{~cm}$. Perbedaan besar yang tampak adalah berkaitan dengan fluktuasi nilai muka laut rata-rata harian dan bulanan tersebut. Hasil perhitungan muka laut rata-rata harian nilainya berfluktuasi dari $142,3-174,4 \mathrm{~cm}$, jadi variasi nilainya sebesar $32,1 \mathrm{~cm}$. Fluktuasi tersebut lebih besar dari yang terukur di perairan Tanjung Emas Semarang dengan kisaran 150,29-170,79 cm pada Oktober 2003 (Siswanto, 2007). Untuk muka laut rata-rata bulanan, nilainya berfluktuasi dari 144,9$160,4 \mathrm{~cm}$, berarti variasi nilainya sebesar $15,5 \mathrm{~cm}$. Tabel berikut memperlihatkan hasil perhitungan muka laut rata-rata harian dan bulanan pada kawasan perairan yang diteliti.

Tabel 1. Hasil perhitungan muka laut rata-rata harian dan bulanan pada perairan sekitar Kota Bitung, Sulawesi Utara.

Table 1. Results of eulculation of sea surface daily and monthly average on the waters around Bitung. North Sulawesi.

\begin{tabular}{|c|c|c|c|c|}
\hline & 1 & ML & Harian (cm) & $*$ \\
\hline & 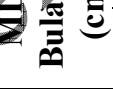 & $\begin{array}{c}\text { Rata- } \\
\text { rata }\end{array}$ & $\begin{array}{c}\text { Variasi } \\
\text { nilai }\end{array}$ & $\sum$ \\
\hline S & 151,6 & 151,9 & $148,2-156,3$ & 1,5 \\
\hline Okt/2008 & 152,6 & 152,9 & $149,4-156,8$ & 1,9 \\
\hline Nop 2008 & 154,9 & 155,3 & $148,9-158,5$ & 2,0 \\
\hline Des 2008 & 160,0 & 160,3 & $156,8-164,3$ & 2,2 \\
\hline Jan 2009 & 160,4 & 161,0 & $157,7-174,4$ & 2,1 \\
\hline Feb 2009 & 159,4 & 159,4 & $154,7-164,6$ & 2,2 \\
\hline Mar 2009 & 158,4 & 158,9 & $153,0-162,1$ & 1,7 \\
\hline Apr 2009 & 157,1 & 157,3 & $153,2-160,7$ & 1,7 \\
\hline Mei 2009 & 155,7 & 156,0 & $153,5-159,6$ & 1,0 \\
\hline Jun 2009 & 152,5 & 152,7 & $149,1-155,7$ & 1,5 \\
\hline Jul 2009 & 147,0 & 147,0 & $142,3-150,7$ & 1,6 \\
\hline Agust 2009 & 144,9 & 145,1 & $142,9-147,8$ & 1,3 \\
\hline MLR Tahunan & 154,5 & 154,8 & & \\
\hline
\end{tabular}

Ket. *Simpangan MLR Harian Terhadap MLR Bulanan (cm)

Berdasarkan tabel hasil perhitungan dapat lebih jelas dilihat variasi nilai muka laut rata-rata harian terhadap perhitungan muka laut rata-rata bulanan. Individual nilai muka laut rata-rata harian memiliki simpangan yang cukup besar apabila diperhadapkan dengan hasil perhitungan muka laut rata-rata bulanan. Besarnya penyimpangan bervariasi dari $1-2,2 \mathrm{~cm}$. Walaupun demikian, individual nilai muka laut rata-rata harian, apabila diperhitungkan secara keseluruhan dengan mencari rataratanya, maka tampak bahwa rata-rata muka laut rata-rata harian memiliki nilai yang hampir sama dengan nilai muka laut rata-rata bulanan yang diperoleh dengan metode admiralti.

Dalam kegiatan pemeruman berskala kecil untuk menghasilkan peta batimetri, sering kali referensi yang digunakan adalah muka laut rata-rata harian melalui durasi pengukuran pasang surut selama $39 \mathrm{jam}$, atau analisis menggunakan filter 
Doodson. Hasil penelitian ini dapat memberikan suatu gambaran mengenai keakuratan peta batimetri yang dihasilkan dengan referensi muka laut rata-rata harian.

Selanjutnya pada gambar berikut divisualisasikan hasil perhitungan muka laut rata-rata harian yang tersebar di sekitar hasil perhitungan muka laut rata-rata bulanan.

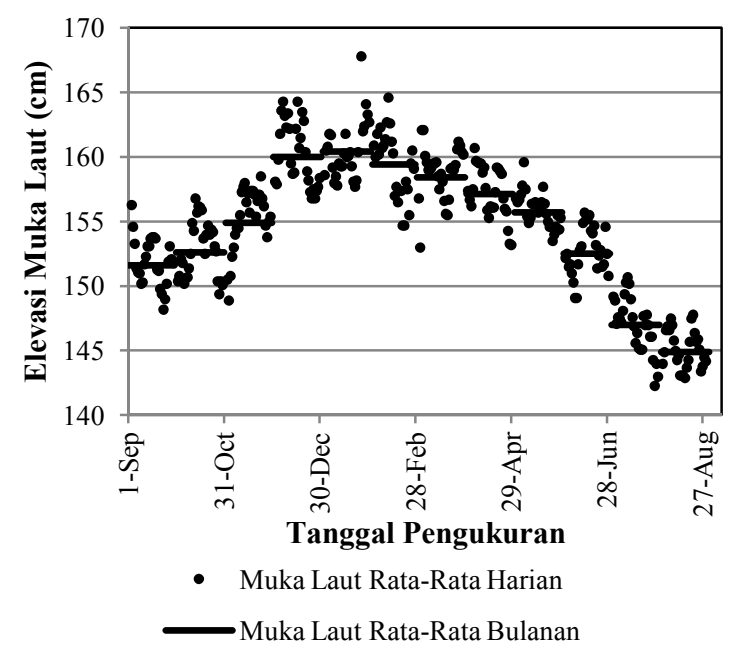

Gambar 2. Muka laut rata-rata harian dan bulanan.

Figure 2. Average of sea level on daily and monthly.

Sama halnya dengan tunggang air pasang surut, fluktuasi nilai muka laut rata-rata harian maupun bulanan merupakan respon dari kondisi jarak bulan dan matahari dengan bumi.)Berdasarkan grafik muka laut rata-rata harian can bulanan jelas tampak nilai yang besar diperolehpada sekitar bulan Desember sampai dengan Februari dan menurun memasuki bulan-buan berlangsungnya musim panas di belahan bumi Utara. Pada perhitungan muka laut ratatrata harian secara nyata diperoleh nilai tertinggi muka laut rata-rata harian terjadi pada tanggal 24 Januari, sedangkan nilai terendah pada tanggal 28 Juli.

Sekalipun terdapat variasi terhadap hasil perhitungan -múka laut rata-rata harian dan bulanan, tetapi seperti yang telah disampaikan terdahulu, hasitymerata-ratakan nilai muka laut rata-rata harian dar bulanan memperoleh nilai yang hampir sama. Hal tersebut memberikan indikasi, nilai muka laut rata-rata yang dapat dijadikan referensi ketinggian adalah yang berdasarkan pada seri data minimal 1 tahun.

\section{KESIMPULAN}

Kisaran tunggang air pasang surut saat perbani di daerah penelitian adalah $47,2-76,3 \mathrm{~cm}$, dengan nilai rata-rata $63,4 \mathrm{~cm}$. Saat pasang surut purnama, tunggang air pasang surutnya berkisar $137-182,5 \mathrm{~cm}$, rata-rata $155,2 \mathrm{~cm}$. Berdasarkan tunggang air pasang surut tersebut, maka pasang surut pada daerah penelitian termasuk dalam golongan microtidal. Muka laut rata-rata tahunan berdasarkan analisis muka laut rata-rata bulanan adalah sebesar $154,5 \mathrm{~cm}$, sedangkan yang berdasarkan muka laut rata-rata harian diperoleh sebesar $154,8 \mathrm{~cm}$.

\section{DAFTAR PUSTAKA}

Bird E. 2008. Coastal geomorphology. $2^{\text {nd }}$ Edition John Wiley \& Sons Ltd, Southern Gate, Chichester. Wst Sússex PO19 8SQ, England. 411p.

Djaja R. 1989a. Pengamatan pasang surut laut untuk penentuan datum ketinggian. Pasang Surut. Penyunting: Ongkosongo OSR dan Suyárso Lembaga Ilmu Pengetahuan Indonesia, Pusat Penelitran dan Pengembangan Oseanologi. Jakarta. p. 149-191.

1989b. Cara perhitungan pasut laut dengan metode admiralti. Pasang Surut. Penyunting: Ongkosongo OSR dan Suyarso, Lembaga Ilmu Pengetahuan Indonesia, Pusat Penelitian dan Pengembangan Oseanologi. Jakarta. p: 40-83.

Pelling HE, Green JAM and Ward SL. 2013. Modeling tides and sea-level rise: to flood or not to flood. www.elsevier com-/locate/ocemod. Ocean Modeling 63 (2013) 21-29.

Pethick J. 1997. An introduction to coastal geomorphology. Edward Arnold Publ. Ltd. New York. 259p.

Pinet PR. 1992. Oceanography, an introduction to the planet oceanus. West Publishing Company, United States of America. 571p.

Pipkin BW, Gorsline DS, Casey RE and Hammond DE. 1977. Laboratory exercises in oceanography. WH. Freeman and Company. New York. 257p.

Pugh DT. 1987. Tides, surges and mean sea level. A handbook for engineers and scientists. John Wiley and Sons Ltd. Great Britain. 472p.

Siswanto AD. 2007. Karakteristik pasang di perairan Tanjung Emas Semarang. Jurnal Kelautan. Vol. 1 no. 1. p: 14-21.

Soeroso. 1989a. Muka laut rata-rata dan aplikasinya dalam jaring geodesi. Pasang Surut. Penyunting: Ongkosongo OSR dan Suyarso. Lembaga Ilmu Pengetahuan Indonesia, Pusat Penelitian dan Pengembangan Oseanologi. Jakarta. p: 192-200.

1989b. Cara memperoleh konstanta pasang surut. Pasang Surut. Penyunting: Ongkosongo OSR dan Suyarso. Lembaga Ilmu Pengetahuan Indonesia, Pusat Penelitian dan Pengembangan Oseanologi. Jakarta. p: 24-39.

Stewart RH. 2008. Introduction to physical oceanography. Department of Oceanography Texas A \& M University. $345 \mathrm{p}$.

Talley LD, Pickard GL, Emery WJ, and Swift JH. 2011. Descriptive physical oceanography: An Introduction. $6^{\text {th }} \mathrm{Ed}$. Elsevier Ltd., London, UK. 555p.

Tomczak M and Godfrey JS. 2005. Regional oceanography: an introduction. Butler \& tanner Ltd, Frome and London. $364 \mathrm{p}$. 